\title{
CONSIDERAÇÕES SOBRE A EXPANSÃO DA INDÚSTRIA DE PAPEL E CELULOSE NO BRASIL A PARTIR DO CASO DA SUZANO PAPEL E CELULOSE ${ }^{1}$
}

\author{
Marta Inez Medeiros Marques² \\ Universidade de São Paulo
}

\begin{abstract}
Resumo: Este artigo aborda a expansão da indústria de papel e celulose no Brasil observada nas últimas décadas, com especial atenção para: o processo de concentração e centralização do capital que afeta as empresas do setor no período; o papel desempenhada pelo Estado neste processo; e o seu impacto no campo. Para melhor fundamentar a análise e situá-la no nível local são apresentados aspectos da trajetória recente da Suzano Papel e Celulose e de suas principais estratégias de territorialização. Constatou-se o significativo impacto da mundialização da economia na indústria de papel e celulose, o crescimento da produção nacional - com destaque para a celulose, que triplicou o volume produzido nos últmos 20 anos -, a consolidação de empresas mundiais e a expansão do plantio de eucalipto e do mercado "florestal" em diferentes regiões do país. O estudo baseou-se em levantamento de material documental, cartográfico e em pesquisa direta, além da análise de dados estatísticos oficiais e de entidades de representação do setor de produção de madeira, papel e celulose. Palavras-chave: Indústria de Papel e Celulose; Suzano Papel e Celulose; Mercado "Florestal"; Estratégias de Territorialização.
\end{abstract}

\section{CONSIDERATIONS ABOUT THE EXPANSION OF THE PULP AND PAPER INDUSTRY IN BRAZIL FROM THE CASE OF SUZANO PAPEL E CELULOSE}

\footnotetext{
${ }^{1}$ Este artigo apresenta parte dos resultados da pesquisa intitulada Análise geográfica da expansão recente da indústria de papel e celulose no campo brasileiro: o caso da Suzano Papel e Celulose, realizada sob minha coordenação no período de jan/2012 a fev/2014. A pesquisa contou com a participação de alunos de graduação e de pós-graduação da Universidade de São Paulo e com o apoio financeiro do CNPq, Processo: 401680/2011-8, Chamada CNPq /CAPES N ${ }^{\circ}$ 07/2011.

${ }^{2}$ Geógrafa e professora doutora do Departamento de Geografia da Universidade de São Paulo (USP). Contato: mimmar@usp.br.
} 


\begin{abstract}
This article discusses the expansion of the pulp and paper industry in Brazil observed in recent decades, with particular attention to: the process of concentration and centralization of capital that affects companies of the sector in the period; the role played by the State in this process; and its impact in the countryside. To better support the analysis and place it at the local level, some aspects of the recent trajectory of Suzano Pulp and Paper and its main territorial strategies are reported. It was noted the significant impact of economic globalization in the pulp and paper industry, the growth of domestic production - especially for cellulose, whose output tripled in the last 20 years -, the consolidation of global companies and the expansion of the eucalyptus plantation and the forestry market in different regions of the country. The study was based on a survey of documentary and cartographic material, direct research, in addition to the examination of statistical data produced by official institutions and by representative bodies of the logging, pulp and paper sectors.
\end{abstract}

Keywords: Pulp and Paper Industry; Suzano Pulp and Paper; Forestry Market; Territorial Strategies.

\title{
Introdução
}

A indústria de celulose apresentou grande crescimento nas últimas décadas no Brasil com o avanço do monocultivo de eucalipto ${ }^{3}$ em extensas áreas do território nacional, especialmente na região de MATOPIBA $^{4}$ e no Mato Grosso do Sul. Esse movimento foi acompanhado pela instalação de imensas plantas industriais em pontos estratégicos ${ }^{5}$ e pelo aumento significativo do volume de celulose produzido e exportado.

A expansão da produção de celulose no país se deve a uma diversidade de fatores e processos que vêm se desenrolando a longo tempo e passam a assumir um novo significado a partir dos anos 1990 em face do avanço da globalização. Dentre eles, destacam-se: a grande disponibilidade de terras e mão de obra baratas; as boas condições edafoclimáticas que, somadas a um elevado nível tecnológico, ${ }^{6}$ resultam na alta produtividade dos plantios, $;^{7} \mathrm{o}$ investimento de capitais estrangeiros no setor

\footnotetext{
${ }^{3}$ A produção de celulose no Brasil é feita a partir do cultivo do eucalipto e do pinus e pode se apresentar de forma integrada à produção de papel ou voltada para a comercialização, o que, neste último caso, tem o mercado externo como o seu principal destino. O plantio do pinus se concentra no sul do país enquanto o do eucalipto está presente nas demais regiões.

${ }^{4}$ A região de MATOPIBA é considerada a última fronteira agrícola do país e sua denominação é um acrônimo formado com as iniciais dos estados que a compõem (Maranhão, Tocantins, Piauí e Bahia). Em 6 de maio de 2015 foi assinado pela Presidenta Dilma Rousseff o Decreto $n^{\circ}$ 8.447, que dispõe sobre o Plano de Desenvolvimento Agropecuário do MATOPIBA (PDA-MATOPIBA) (Disponível em <http://www.planalto.gov.br/ccivil_03/_Ato2015-2018/2015/Decreto/D8447.htm>. Acessado em: 11 jun. 2015).

5 A indústria de celulose é instalada na proximidade das áreas produtoras de matéria-prima e do entroncamento de eixos de transporte e circulação por onde é escoada a sua produção.

${ }^{6}$ A tecnologia empregada no desenvolvimento da silvicultura é nacional, enquanto a tecnologia materializada nas máquinas utilizadas no corte da madeira e na indústria de processamento de papel e celulose é de origem estrangeira.

${ }^{7} \mathrm{O}$ plantio de árvores no Brasil apresenta uma produtividade cerca de $30 \%$ maior do que em qualquer outro lugar do mundo. O Incremento Médio Anual (IMA) por hectare de eucalipto ou produtividade média dos plantios em função da área plantada era de 39,4 m³/ha/ano em 2006 e atingiu 40,7
} 
e as políticas de incentivo adotadas pelo Estado brasileiro. Hoje o Brasil é o maior exportador mundial da celulose de fibra curta. ${ }^{8}$

O Estado, dentre outras ações, tem apoiado por meio da concessão de financiamentos a concentração e centralização de capitais em setores específicos da economia, como é o caso do setor de produção de celulose e papel, contribuindo de maneira efetiva para a formação de grandes empresas de atuação mundial. Neste contexto, a indústria de celulose mais do que triplicou a sua produção em vinte anos, alcançando em 2012 um volume de cerca de 14 milhões de toneladas, fazendo com que o Brasil passasse a ser o quarto maior produtor mundial de celulose, depois dos Estados Unidos, China e Canadá (BRACELPA, 2014).

Enquanto isso, a produção de madeira na silvicultura para abastecer o setor de papel e celulose mais do que dobrou, saltando de 32 milhões de $\mathrm{m}^{3}$ em 1990 para 70 milhões de $\mathrm{m}^{3}$ em 2010 e 74 milhões de $\mathrm{m}^{3}$ em $2012^{9}$.

Segundo a RISI Consultoria o Brasil exportou em 2010 5,3 milhões de toneladas de celulose acima do registrado em 2000, “o que levou o país a se tornar o segundo maior exportador de celulose, atrás apenas do Canadá (o Brasil era o quarto maior exportador em 2000)." (VIDAL; DA HORA, s/d, p. 359) ${ }^{10}$. Cerca de $62 \%$ da celulose produzida no país em 2013 foi exportada e se destinou principalmente para a Europa, China e América do Norte, onde serão realizadas atividades de maior valor agregado; enquanto a produção de papel, voltada sobretudo para o abastecimento do mercado interno, foi exportada num volume equivalente a cerca de $18 \%$ do total produzido, sendo em sua maior parte para a América Latina e Europa (BRACELPA, 2013, p. 21 e 24).

O campo brasileiro tem passado por intensas mudanças associadas a processos econômicos globais e à atual redefinição da divisão internacional do trabalho. A reestruturação da produção de papel e celulose em nível nacional está vinculada ao desenvolvimento geral do setor no mundo, marcado pela consolidação de grandes grupos empresariais e sua atuação em escala mundial ${ }^{11}$.

$\mathrm{m}^{3} / \mathrm{ha} / \mathrm{ano}$, em 2012. A China, com produtividade média de $30,8 \mathrm{~m}$ 3/ha/ano em 2012, apresenta o segundo maior IMA mundial para a produção de eucalipto (ABRAF, 2013).

${ }^{8}$ A celulose de fibra curta é originária do eucalipto e a de fibra longa é proveniente do pinus. Até o ano de 2003, a participação da celulose de fibra longa no mercado internacional era maior do que a de fibra curta, invertendo-se a partir de então (BIAZUS et al., 2010a, p. 125).

9 IBGE, Produção da Extração Vegetal e da Silvicultura. Disponível em: http://www.sidra.ibge.gov.br/bda/tabela/protabl.asp?c=291\&z=t\&o=3\&i=P. Acessado em: 20 out. 2013.

${ }^{10} \mathrm{O}$ Canadá produz celulose a partir do pinus, ou seja, de fibra longa.

${ }^{11}$ As 20 maiores empresas produtoras de celulose no mundo em 2009, com seus respectivos países de origem, eram, segundo a Hawkins Wright Consultores: $1^{\mathrm{a}}$ Fibria (Brasil), $2^{\mathrm{a}}$ Arauco (Chile/Argentina), $3^{\mathrm{a}}$ April (Indonésia/China), $4^{\mathrm{a}}$ APP (China/Indonésia/Canadá), $5^{\mathrm{a}}$ CMPC (Chile), $6^{\text {a }}$ Sodra (Suécia/Noruega), $7^{\mathrm{a}}$ Weyerhaeuser (EUA/Canadá), $8^{\mathrm{a}}$ UPM-Kymmene (Finlândia/Uruguai), $9^{\mathrm{a}}$ Botnia/M-real (Finlândia), $10^{\mathrm{a}}$ Stora Enso (Países Nórdicos), 11 ${ }^{\mathrm{a}}$ Canfor Corp. (Canadá), $12^{\mathrm{a}}$ Suzano (Brasil), 13 ${ }^{\mathrm{a}}$ Domtar (EUA/Canadá), $14^{\mathrm{a}}$ Ilim (Rússia), $15^{\mathrm{a}}$ Mercer (Canadá/Alemanha), $16^{\mathrm{a}}$ IP (EUA/Rússia/França), 17 $7^{\text {a }}$ Georgia Pacific (EUA), 18 a ENCE (Espanha), 19 ${ }^{a}$ West Fraser (Canadá) e $20^{\text {a }}$ CENIBRA (Brasil) ${ }^{11}$ (BIAZUS et al., 2010b, p. 341). 
A cadeia produtiva de papel e celulose se estende por 18 estados brasileiros, mas sua produção se concentra, sobretudo, nos estados de São Paulo, Minas Gerais, Bahia e Mato Grosso do Sul. Entre suas maiores empresas, destacam-se as de capital nacional, como a Fibria, a Suzano, a Eldorado e a Klabin, apesar da presença crescente de capitais estrangeiros no setor ${ }^{12}$.

Este artigo aborda a expansão da indústria de papel e celulose no Brasil observada nas últimas décadas, com especial atenção para o processo de concentração e centralização do capital que afeta as empresas do setor no período; a atuação do Estado neste processo e o seu impacto no campo. E, para melhor fundamentar a análise e situá-la no nível local, são apresentados aspectos da trajetória recente da Suzano Papel e Celulose e de suas principais estratégias de territorialização.

Optou-se pelo estudo de uma empresa específica por acreditar que tal caminho permitiria uma melhor compreensão das relações estabelecidas entre os processos que têm lugar no campo e o que ocorre em outros espaços e escalas geográficas mais amplas. A escolha da Suzano Papel e Celulose como objeto de pesquisa se deu devido a várias razões, a saber, por ser esta uma das maiores e mais tradicionais empresas nacionais atuantes no setor e a primeira dentre elas a abrir o seu capital em uma bolsa de valores, o que se deu em 1980; por sua atuação protagonista no desenvolvimento de tecnologia nacional para a melhoria genética do eucalipto aplicada à produção de celulose, com pesquisa de ponta na área de biotecnologia ${ }^{13}$; por atuar ativamente nos novos mercados criados pela economia verde, sendo a primeira empresa com plantação de eucalipto a vender crédito de carbono na Chicago Climate Exchange em 2004; e por ter a região do MATOPIBA como principal área de expansão para seus novos investimentos produtivos.

Foi adotada uma metodologia qualitativa com a realização do levantamento de material bibliográfico, de imagens e de dados estatísticos do governo (IBGE, BNDES) e entidades representatitvas do setor (BRACELPA e ABRAF) relativos à indústria de papel e celulose no país. Também foi realizado o levantamento de documentos e artigos sobre o tema produzidos pela própria Suzano Papel e Celulose e pela imprensa (local e nacional), por representantes da sociedade civil (movimentos sociais e ONGs) e pela academia.

\footnotetext{
12 São exemplos da participação internacional entre as grandes empresas instaladas no país, a International Paper (empresa norte-americana); a MWV Rigesa (também norte-americana); a Cenibra (empresa de capital japonês) e a Veracel (joint venture entre a Fibria, empresa brasileira, e a Stora Enso, empresa de origem sueco-finlandesa).

${ }^{13}$ A Suzano tem investido no desenvolvimento de variedades transgênicas do eucalipto por meio de sua subsiadiária FuturaGene Brasil. Em 9 de abril de 2015, a empresa obteve da Comissão Técnica Nacional de Biossegurança (CTNBio) o licenciamento para uso comercial de uma variedade de eucalipto transgênico batizada de H421. Ela será a primeira empresa no mundo a usar em escala comercial o eucalipto transgênico. (O Estado de São Paulo [online], 10/04/2015. Diponível em: $<$ http://economia.estadao.com.br/noticias/geral,suzano-usara-1-eucalipto-transgenico-do-mundo-imp ,1667120>. Acessado em 10 abr. 2015).
} 
A partir do desenvolvimento da pesquisa identificou-se as áreas de atuação da Suzano nos estados do Maranhão, São Paulo e Bahia e foram selecionados os lugares para a realização do trabalho de campo. Foram visitadas as regiões de Imperatriz (MA) ${ }^{14}$ e do Leste Maranhense (MA) ${ }^{15}$ em abril/maio e agosto de 2012, respectivamente; os municípios de São Luís do Paraitinga (SP), em junho de 2012; Salesópolis (SP), em maio de 2013; São Miguel Arcanjo (SP), em maio de 2012 e novembro de $2013^{16}$; e o município de Mucuri (BA), em março de $2013^{17}$.

Foram realizadas entrevistas semiestruturadas junto a funcionários da empresa, moradores, autoridades locais, trabalhadores do setor e lideranças de movimentos sociais. De um modo geral foi difícil o acesso a funcionários da Suzano devido às dificuldades criadas pela empresa, apesar disso foram entrevistados dois funcionários da gerência socioambiental da Unidade Florestal do Maranhão e um da área de produção da Unidade Florestal em São Paulo, além de um exfuncionário aposentado do segmento da produção agrícola em São Paulo.

$\mathrm{O}$ artigo encontra-se dividido em três partes, além da introdução e das considerações finais, assim discriminadas: mundializaçãoda economia e a indústria de papel e celulose; expansão do plantio de eucalipto e do mercado "florestal"" e a empresa Suzano Papel e Celulose.

\section{Mundialização da economia e a indústria de papel e celulose}

Os anos 1990 marcam a consolidação da mundialização ou globalização da economia $^{19}$ iniciada com a crise econômica mundial da década de 1970 . Neste período o sistema capitalista passa por mudanças significativas em relação às relações de trabalho e regime salarial; a repartição dos rendimentos no interior dos países e também entre eles, com uma retomada importante de rendimentos rentistas, e a repartição entre investimento e aplicações financeiras na economia mundial (CHESNAIS, 1996, p. 10).

\footnotetext{
${ }^{14}$ Agradecemos o apoio fundamental que nos foi dado na ocasião por Francisco Lima e Luciléa Lopes, professores da Universidade Estadual do Maranhão (UEMA).

${ }_{15}$ Nesta viagem fomos acompanhados por José Arnaldo dos Santos Ribeiro Junior - orientando de mestrado e integrante da equipe de pesquisa - e por Josoaldo Rego, professor da Universidade Federal do Maranhão (UFMA) e estudioso da região.

${ }^{16}$ O campo em São Paulo contou com a participação de Taciana Ribeiro e Olga Geremias, alunas de graduação em Geografia da Universidade de São Paulo e integrantes da equipe de pesquisa.

${ }^{17}$ Campo realizado por Andrei Cornetta, mestre e pesquisador integrante da equipe de pesquisa.

${ }^{18}$ Os termos floresta e florestal aparecem aspeados para indicar o uso ideológico desta denominação feito por empresas, órgãos do Estado e outros. Originariamente o termo se refere a uma formação vegetal natural que apresenta biodiversidade, entre outras características ausentes nas áreas de monocultivo de árvores.

${ }^{19}$ Esse processo deve ser compreendido no interior do movimento de expansão e reprodução do capital e de suas reiteradas crises de sobreacumulação, sendo o resultado de uma estratégia das classes dominantes para enfrentar a crise econômica dos anos 1970 (HARVEY, 2004).
} 
Avança o processo de concentração e centralização de capitais com a reestruturação de grandes empresas transnacionais ou grandes grupos oligopolistas com capacidade de adotar uma abordagem e uma conduta globais. A mundialização atinge sobremaneira a indústria de papel e celulose, que é atravessada por um movimento continuado de fusão e aquisição entre as empresas do setor e consequente redução da participação das empresas de menor porte.

A formação dessas organizações de alcance global conta com forte apoio das instituições de caráter estatal. A produção de papel e celulose, caracterizada pelo investimento intensivo em capital, é fortemente dependente de recursos públicos desde a sua origem e continua sendo. Para isso tem contado com a firme colaboração dos bancos de desenvolvimento nacionais e multilaterias, a exemplo do BNDES e do Banco Mundial ${ }^{20}$.

A reestruturação do setor de papel e celulose em nível global está relacionada a uma onda de investimentos de capitais de países como Finlândia, Estados Unidos e Canadá, tradicionais produtores, em direção à América Latina (Brasil e Chile), à Ásia (Indonésia e Malásia) e à Rússia. Uma série de fatores vinculados à produção e circulação contribuiu para essa mudança na geografia do setor de papel e celulose, donde destacam-se, de um lado, o aumento dos custos de transporte da madeira nos países do Norte devido à interiorização dos cultivos e ao crescimento da distância das áreas de produção em relação às áreas de processamento e uma maior regulação incidente sobre o setor, com o crescimento dos custos de gestão da produção; do outro, a emergência de fornecedores de fibra a baixo custo em países do Sul e na Rússia, ancorada, em sua maioria, em vantagens comparativas de base natural - como a abundância de luz solar e de água - e nos baixos custos da terra e da mão de obra.

O desenvolvimento geográfico desigual do setor também está relacionado a mudanças na esfera do consumo. Nessa década registra-se um declínio continuado do consumo de papel nos países da América do Norte e Europa Ocidental devido à contração do mercado de mídia impressa em favor da mídia digital; enquanto nos países emergentes da região Ásia-Pacífico, com destaque para a China e a Índia, observa-se o crescimento do consumo de papel e da mídia impressa, dado o aumento da escolarização da população. Em resposta às alterações no mercado de consumo também se observou uma mudança de foco na indústria de papel, com a ampliação da produção de papéis sanitários e material para embalagens e empacotamento (WHITEMAN, 2005).

\footnotetext{
${ }^{20}$ Outros atores têm sido as agências multilaterais como o Fundo Monetário Internacional (FMI) e a Organização das Nações Unidas para a Alimentação e a Agricultura (FAO). Entre os bancos de desenvolvimento multilaterais, além do Banco Mundial e sua Corporação Financeira Internacional (CFI), destaca-se o Banco Europeu de Investimento (BEI), o Banco Nórdico de Investimento (BNI), e bancos regionais, como o Banco Asiático de Desenvolvimento (ADB). Todos financiam consultorias e projetos de empresas plantadoras de árvores (WORD RAINFOREST MOVEMENT. Velhos e novos investidores por detrás dos monocultivos de árvores. Boletim Mensal WRM, 191, jun 2013, p. 5. Disponível em: <http://wrm.org.uy/pt/files/2013/06/Boletim191.pdf. Acessado em 30 ago. 2013.
} 
Em meados da década de 1990 o Estado brasileiro adotou uma série de medidas no sentido de uma maior abertura e internacionalização da nossa economia, aliadas a um ajuste financeiro de perfil neoliberal (redução do déficit fiscal e atração de investimentos externos). Ele recuou do papel de investidor direto em setores-chave da economia nacional - tais como mineração, siderurgia, papel e celulose -, passando a atuar, sobretudo, como agente financeiro; e as empresas privadas ganharam maior poder no jogo político-econômico, ampliando o seu alcance no território nacional.

No período entre 2001 e 2010 a capacidade produtiva das plantas industriais instaladas no país dobrou, implicando a necessidade de aportes em capital cada vez maior. A busca de integração competitiva no mercado mundial e de equilíbrio cambial contribuiu para justificar o amplo apoio do Estado então concedido às empresas de papel e celulose.

O Banco Nacional de Desenvolvimento Econômico e Social (BNDES) teve uma participação ativa no período, tanto financiando a implantação de novos projetos do setor, como também investimentos em expansão e modernização. Dentre os novos projetos que contaram com recursos do Banco destacam-se, conforme data de início do apoio, uma nova linha na unidade da Aracruz, no município de Aracruz (ES) em 2000; a implantação da Veracel no sul da Bahia, em 2003; nova linha na planta da Suzano em Mucuri (BA), em 2005; a instalação da Votorantim Celulose e Papel (VCP) (com permuta de ativos com a Internacional Paper) ${ }^{21} \mathrm{em}$ Três Lagoas (MS), em 2007²2; a implantação da Eldorado em Três Lagoas (MS), em 2010; a implantação da planta da Suzano em Imperatriz (MA), em 2010 (VIDAL; DA HORA, 2011).

Os desembolsos diretos do departamento do $\mathrm{BNDES}^{23}$ responsável pela indústria de papel e celulose e painéis de madeira no referido decênio se concentraram em sua maior parte no setor de celulose, que captou $49 \%$ do volume dos recursos, seguido pelo de papel, com 23\%, e pelo de "florestas" plantadas, com 18\% (VIDAL; DA HORA, op. cit., p. 148). Os Investimentos Diretos Estrangeiros (IDE) direcionados a essas atividades, que passaram a ingressar no país principalmente nos anos 2000, também privilegiaram a indústria de papel e celulose em detrimento do setor "florestal" (MONTEBELLO, 2010, p. 66-67).

Intensifica-se o processo de oligopolização da cadeia produtiva de papel e celulose, sobretudo no subsetor produtor de celulose, que mais do que triplicou o

\footnotetext{
${ }^{21} \mathrm{O}$ termo ativo é utilizado para expressar os bens, valores, direitos e assemelhados que formam o patrimônio de uma instituição econômica e que podem ser avaliados em termos monetários.

${ }^{22}$ A VCP transferiu à International Paper a unidade de produção de celulose e papel e sua área cultivada com eucalipto em Luiz Antônio (SP) e recebeu em troca ativos referentes a uma planta industrial de celulose em construção em Três Lagoas (MS), além de terras e áreas plantadas no entorno (VALOR ECONÔMICO, 14/12/2012).

23 "As operações diretas são realizadas diretamente com o BNDES ou por um mandatário, já as indiretas são realizadas por meio de instituição financeira credenciada, ou mediante o uso do Cartão BNDES.” (VIDAL; DA HORA, op. cit., p.134)
} 
seu volume de produção em vinte anos (MONTEBELLO, 2010, p. 69). As principais empresas brasileiras produtoras de celulose de mercado passaram por processos de reestruturação, aumentando sua competitividade frente às grandes empresas mundiais. São exemplos de reestruturação: a Bahia Sul, cujas ações pertencentes à Vale foram compradas em 2001 por sua sócia, a empresa Suzano, dando origem à unidade Mucuri da Suzano; a Celulose Nipo-Brasileira S/A (CENIBRA), cuja participação da Vale foi comprada por seu sócio Japan Brazil Paper and Pulp Resources Development Co. Ltd. (JBP) ${ }^{24}$, em 2001; a CMPC Celulose Riograndense, antiga Riocell, que pertenceu ao grupo Klabin até 2003, quando foi comprada pela Aracruz, tendo sido vendida posteriormente para o grupo CMPC do Chile, em 2008; e a Aracruz, que foi incorporada pela VCP em 2009, dando origem à Fibria.

No segmento de papéis ocorre processo semelhante, porém a concentração e centralização de capitais foram maiores entre as empresas produtoras de celulose em face das exigências do mercado externo, comparando-se às indústrias de papel, voltadas prioritariamente para o mercado interno (MONTEBELLO, 2010, p. 5960). Em 2008 cerca de $73 \%$ do total da produção, considerando as indústrias integradas e de mercado, concentravam-se em apenas cinco empresas: Fibria, Suzano, Klabin, CENIBRA e International Paper do Brasil (BIAZUS et al., 2010b, p. 318).

Embora a crise econômica internacional de 2008 tenha reduzido o consumo e os preços dos produtos do setor de papel e celulose, atingindo algumas empresas brasileiras, o seu impacto foi limitado. "No segmento de celulose, a valorização do real e a retração da demanda na Europa e nos Estados Unidos, principais destinos do produto brasileiro, não prejudicaram os volumes exportados, que devem crescer dois dígitos em 2009, suportados pela demanda chinesa" (BIAZUS et al., 2010a, p.119-120) Os preços tornaram a subir gradativamente no período pós-crise e as empresas continuaram se expandindo (ABRAF, 2013, p, 31 e 69).

No entanto, a conjuntura crítica revelou a efetividade do apoio e proteção do Estado ao capital também em situações excepcionais. A Aracruz foi a empresa brasileira mais prejudicada com a crise de 2008, devido à sua forma de atuação no mercado financeiro com exposição a contratos cambiais de elevado risco ${ }^{25}$. Em cerca de 50 dias, entre setembro e novembro de 2008, a Aracruz - uma das maiores fabricantes mundiais de celulose de eucalipto e companhia com ações de grande liquidez no Brasil e no exterior - passa a valer em bolsa menos de um terço de antes do início da crise (COSTA, 2012).

\footnotetext{
${ }^{24}$ Consórcio de empresas japonesas.

25 "Os contratos de derivativos tóxicos chegaram a render à Aracruz um bom dinheiro. No primeiro semestre de 2008, trouxeram pouco mais de R\$ 110 milhões ao caixa, apesar de terem sido contratados apenas no segundo trimestre. O retorno obtido era o equivalente a reduzir em cerca de $8 \%$ o custo de produção da companhia (...). Entre 2003 e 2008, as transações nesse mercado chegaram a render ganhos de US\$ 500 milhões" (COSTA, 2012).
} 
A solução para evitar a falência da empresa se deu por meio de uma negociação em que o BNDES, que já era acionista da Aracruz, com 12,5\% do capital votante, entrou com um aporte de $\mathrm{R} \$ 2,65$ bilhões na formação do capital da nova empresa criada a partir da aquisição da Aracruz pela VCP, a Fibria. Ao final, a participação do banco na empresa ficou maior que a do próprio Grupo Votorantim. A BNDES $\operatorname{Par}^{26}$ ficou com 34,9\% da Fibria, a VCP, com 29,3\%, e os restantes $35,8 \%$ ficaram no mercado ${ }^{27}$ (COSTA, 2012)

De maneira geral, este período se caracteriza por mudanças na composição societária das indústrias de papel e celulose com a redução da participação direta do Estado nas empresas e o crescimento do fluxo de investimentos estrangeiros diretos. Observam-se mudanças frequentes no controle acionário entre capitais nacionais e estrangeiros e a formação de alianças estratégicas entre os grupos.

\section{Expansão do plantio de eucalipto e do mercado "florestal"}

No Brasil a atividade do plantio de árvores é desenvolvida por três atores distintos: produtores independentes, empresas verticalizadas e empresas gestoras de investimentos "florestais". Os primeiros, em sua maioria, são classificados como pequenos e médios produtores, enquanto as empresas verticalizadas e as empresas gestoras de investimentos "florestais" são produtores de grande porte (ABRAF, 2013, p. 80).

Os produtores independentes são proprietários de terras que investem na silvicultura como fonte de renda a partir da comercialização da madeira em tora. Podem estabelecer contratos de suprimento, contratos de parceria operacional como o fomento ${ }^{28}$ ou atuar de forma independente no mercado. As empresas consumidoras de madeira geralmente controlam as operações relacionadas ao cultivo, de modo a assegurar a qualidade da matéria-prima que será consumida na fábrica (ABRAF, 2013).

As empresas verticalizadas produzem para o abastecimento de sua própria unidade industrial. As empresas de gestão de investimentos "florestais" $\left(\right.$ TIMO's $^{29}$, que podem ser vinculadas ou não a fundos de pensão estrangeiros,

\footnotetext{
${ }^{26}$ Subsidiária do BNDES e gestora de suas participações sociais em outras empresas.

${ }^{27}$ A transação foi ainda mais abrangente e, como parte da negociação, o Banco do Brasil comprou $49,9 \%$ do Banco Votorantim (COSTA, 2012).

28 "O fomento florestal é uma modalidade de estímulo à produção de madeira por pequenos e médios proprietários de terra, com a garantia de compra da produção, boa rentabilidade e baixo risco. Os custos iniciais e de assistência técnica são assumidos pelas empresas fomentadoras" (BIAZUS et al., 2010a, 115)

${ }^{29}$ A denominação TIMO vem do inglês e é o acrônimo de Timber Investment Management Organizations. Essas empresas foram criadas nos Estados Unidos com o objetivo de organizar e administrar as parcerias de investidores institucionais como os fundos de pensão e institutos de seguros com os investimentos "florestais". Elas passam a apresentar crescimento significativo neste
} 
atuam como produtoras independentes no mercado. Elas realizam o plantio, compra e venda de áreas de monocultivo de árvores - que assumem o caráter de ativos "florestais" "30 - e estabelecem contratos de fornecimento de madeira, que são em geral de longo prazo, envolvendo mais de um ciclo produtivo ${ }^{31}$ (VALOR ECONÔMICO, 23/10/2010). Fazem, assim, a intermediação entre investidores distantes (que lucram com a especulação em bens imóveis e a produção de "florestal") e consumidores de madeira.

$\mathrm{O}$ aumento significativo da capacidade de processamento das novas unidades industriais e, consequentemente, do volume de madeira por elas demandado, implica a necessidade de grandes investimentos em terra e ativos "florestais". Esse fato, aliado ao peso crescente do capital imobilizado na planta industrial, levou as empresas processadoras a buscarem formas complementares de fornecimento de matéria-prima além da produção em terras próprias - como o arrendamento e o fomento -, e a pressionarem o Estado para a promoção de políticas de incentivo à expansão das áreas cultivadas.

Além disso, o crescimento da demanda industrial por madeira gerou no final do século passado um desequilíbrio em relação à oferta disponível, o que resultou na elevação do preço deste produto e tornou o investimento em sua produção bastante atrativo, dinamizando este mercado ${ }^{32}$.

Assim, foram ampliados de forma significativa os programas empresariais de fomento à silvicultura conforme diferentes modelos ou estratégias, a saber: doação de mudas, venda de mudas, renda antecipada e parceria florestal ${ }^{33}$. Além destes, nos quais são fornecidos insumos e assistência técnica aos produtores, "outra estratégia que vem sendo adotada pelas empresas, principalmente as de papel e celulose, é a facilitação ao acesso às linhas de financiamento, atuando como avalistas nos empréstimos destinados ao plantio de florestas" (MENDES, 2005, p. 42).

Por outro lado, os grandes investimentos no plantio de eucalipto, que sempre estiveram vinculados à indústria de transformação, começam a receber aportes de outros agentes econômicos a partir do início dos anos 2000, com a entrada no país

país a partir dos anos 1980 e somente se expandem para outros países na última década (SILVA, 2013, p.28)

30 "Os monocultivos industriais de árvores se converteram em ativos do mercado florestal, cujos atrativos incluem sua resiliência diante das crises, além de oferecer investimentos de longo prazo relativamente seguros, dos quais se obtém uma rentabilidade considerável em comparação com o pouco risco que representam, e permitem diversificar o risco" (WORLD RAINFOREST MOVEMENT, 2013, p. 6)

${ }^{31} \mathrm{O}$ ciclo de desenvolvimento do eucalipto para a produção de celulose no Brasil é de cerca de sete anos.

32 O preço da madeira de eucalipto apresentou no período compreendido entre 1997 e 2005 um crescimento acumulado de $329 \%$, representando um crescimento médio anual da ordem de $20 \%$ (MENDES, 2005, p. 9). Uma análise mais detalhada da evolução recente dos mercados interno e externo de papel e celulose e de sua matéria-prima pode ser encontrada em Montebello (2010).

${ }^{33}$ Para conhecer detalhes sobre como se caracterizam essas estratégias, ver Mendes (2005, p. 60-61). 
de grandes produtores independentes - as empresas de gerenciamento de investimento em área “florestal" ou TIMO's. No Brasil as primeiras operações das TIMO's envolveram florestas nativas na Amazônia.

As TIMO's têm se difundido num contexto marcado pelo surgimento de novas iniciativas financeiras relacionadas ao plantio de árvores em bases industriais. Essa atividade tem se mostrado atraente para os investidores institucionais ${ }^{34}$ por gerar rendimentos a partir do crescimento biológico das plantas e do aumento no preço da madeira e da terra, com excelentes perspectivas de retorno em longo prazo ${ }^{35}$ calcula-se um retorno financeiro de aproximadamente $10 \%$ ao $\mathrm{ano}^{36}$. O negócio com ativos "florestais" é considerado pelos investidores institucionais uma aplicação de caráter "conservador" devido ao seu baixo risco e tem sido visto como uma alternativa contracíclica, num contexto em que os retornos do investimento em ações e títulos estão em baixa (UNFF, 2012, p. 32).

As TIMO's têm adotado diferentes estratégias para iniciar suas atividades no Brasil, dentre elas a aquisição de uma empresa já existente, o desenvolvimento de parceria com uma empresa local ou o estabelecimento de sua própria empresa. Os negócios destes empreendimentos no país têm se concentrado principalmente na aquisição dos ativos "florestais" em idade adulta (SILVA, 2013, p. 28.). "Porém, as formas de negociação são as mais diversas possíveis, podendo incluir aspectos relativos à reposição florestal, garantia de recompra da madeira, estabelecimento de preço, entre outros" (MENDES, 2005, p. 45). Ressalta-se a atuação relativamente recente de fundos florestais ou TIMO's em arrendamentos "florestais" 37.

O Hancock Timber Resources Group, considerado a maior TIMO do mundo com mais de US\$ 8 bilhões de ativos sob sua gestão, chegou ao Brasil em 2005 e em 2009 já era proprietária de 20 mil ha de plantio de pinus no Paraná. A Nemus tem atuado tanto na prospecção de negócios como na gestão dos ativos "florestais" em parceria com diversas TIMO's estrangeiras. A Nemus contava com parceria de três fundos estrangeiros, cujos investimentos somavam US\$ 1,5 bilhão, sendo responsável pela administração de $120 \mathrm{mil}$ ha de "florestas" plantadas em 2009. A

\footnotetext{
34 “Grandes fundos de pensão, companhias de seguro, fundações e fundos patrimoniais têm mostrado interesse em investir no monocultivo de árvores como uma pequena parte de seu diversificado portfólio de investimentos. Geralmente estes fundos operam por meio de TIMO's ou REIT's [Fundos de Investimento Imobiliário] que administram a terra em nome dos investidores" (UNFF, 2012, p. 32).

${ }^{35}$ Esse tipo de investimento caracteriza-se por atrair investidores com perfil de longo prazo, como fundos de pensão, fundos patrimoniais e family offices (consultoria especializada na administração de recursos financeiros dos donos de empresas e de seus herdeiros), entre outros.

36 A empresa papeleira Klabin iniciou em 2009 um contrato de parceria com um fundo de investimentos europeu com duração prevista de 28 anos (Ver em: http://panificacaobrasileira.com.br/2009/noticias/klabin-faz-plantio-com-fundo-europeu. Acessado em: 12 jan. 2014).

37 "O modelo de operação, comum nos Estados Unidos e na Europa, baseia-se na fixação em contrato da forma de gestão e de remuneração" (BIAZUS, et al., 2010a, p. 116)
} 
Corus Agroflorestal possuía 4 mil ha de plantio de eucalipto em Campo Grande e Três Lagoas, no Mato Grosso do Sul, em 2009, voltados para o fornecimento à indústria de papel e celulose. Essa empresa é mantida com recursos do Fundo de Investimento em Participação (FIP) Floresta do Brasil, da Claritas Investimentos, fundada em 1999 e vendida para o Principal Financial Group, tradicional companhia americana do setor financeiro, em 2012. (GAZETA MERCANTIL, 04/03/2009). Segundo estudos do BNDES, as principais TIMO'S no Brasil são o Global Forest Partners (GFP), o Hancock Timber Resource Group (HTRG), o Resource Management Services (RMS) e o RMK Timberland Group (BIAZUS, et al., 2010a, p. 116) ${ }^{38}$.

A Vale Florestar administra um fundo "florestal" formado com capitais nacionais e mantido pela Vale, pelo BNDES e por fundos de pensão dos funcionários da Caixa Econômica Federal (Funcef) e da Petrobras (Petros). Ela possui extensas áreas plantadas com eucalipto e também espécies nativas em terras próprias e arrendadas no Pará, com as quais realiza negócios relacionados à exploração de madeira e futuramente com o mercado de crédito de carbono ${ }^{39}$.

Há muita dificuldade para se obter informações precisas sobre qual a real participação dessas empresas em investimentos "florestais" no Brasil hoje. Conforme reportagem do Boletim Brasil Econômico, as TIMO's eram responsáveis por cerca de $20 \%$ da produção "florestal" no Brasil em 2010 (BRASIL ECONÔMICO, 11/02/2010, p. 5). De acordo com Biazus et al., havia uma perspectiva bastante favorável à expansão das TIMO's nesta ocasião e estimava-se que fossem investidos no país pelos fundos florestais até 2015 cerca de $\mathrm{R} \$ 4$ bilhões, o que acarretaria a diminuição do percentual de florestas próprias pelos setores de base "florestal" para o patamar de 60\% (BIAZUS, et al., 2010a, p. 118).

Porém, restrições referentes à compra de terras por estrangeiros estabelecidas em Parecer da CGU/AGU 01/2008 - RVJ, publicado em outubro de 2010, parecem ter inibido a ação direta de várias dessas empresas e arrefecido os ânimos dos

\footnotetext{
${ }^{38}$ A maior parte dessas TIMO's são associadas à Ibá. A Ibá foi criada em abril de 2014 e é a entidade que representa as 61 empresas e nove entidades estaduais de produtos originários do cultivo de árvores plantadas, com destaque para painéis de madeira, pisos laminados, celulose, papel, florestas energéticas e biomassa, além dos produtores independentes de árvores plantadas e investidores financeiros. Ela reúne as empresas que participavam da Associação Brasileira da Indústria de Painéis de Madeira (Abipa), da Associação Brasileira da Indústria de Piso Laminado de Alta Resistência (Abiplar), da Associação Brasileira dos Produtores de Florestas Plantadas (ABRAF) e da Associação Brasileira de Celulose e Papel (Bracelpa). (Disponível em: http://www.iba.org/pt/entidade/introducao. Acessado em: 11 jun. 2015).

39 "No município de Dom Eliseu, no nordeste do Pará, uma das áreas mais devastadas da Amazônia, 68 fazendas de gado e soja estão sendo convertidas em eucalipto e mata nativa, com investimentos já realizados de $\mathrm{R} \$ 300$ milhões. Os recursos têm como origem o Vale Florestar, fundo de investimento em participações (FIP) com aporte de $\mathrm{R} \$ 610$ milhões, destinado a recobrir áreas degradadas com árvores para exploração econômica de madeira, principalmente para papel e celulose, e transações futuras com crédito de carbono" (VALOR ECONÔMICO, 23/12/2010).
} 
investidores estrangeiros, embora elas continuem operando no país e aplicando recursos originários de investidores nacionais e estrangeiros.

Em face do desequilíbrio entre procura e oferta de madeira, a outra estratégia adotada pelos representantes das indústrias consumidoras desta matéria-prima foi pressionar o Estado, alegando haver o risco de "apagão florestal" - o que levou o Governo Federal a instituir o Programa Nacional de Florestas (PNF) ${ }^{40}$ por meio do Decreto ${ }^{\circ} 3.420$, em 2000.

O Programa visava dinamizar o mercado de produção "florestal" no Brasil e aliviar o peso dos investimentos do setor industrial para assegurar a madeira necessária ao seu abastecimento ${ }^{41}$. Dentre os seus objetivos declarados, destacamse os de fomentar as atividades de silvicultura, notadamente em pequenas e médias propriedades rurais; e apoiar o desenvolvimento das indústrias de base "florestal" e ampliar os mercados interno e externo de produtos e subprodutos da silvicultura. Tal programa estava subordinado à Política Nacional do Meio Ambiente, conduzida pelo Ministério do Meio Ambiente.

O PNF disponibilizou recursos do BNDES em condições especiais através das linhas de crédito do Programa de Plantio Comercial de Florestas (PROPFLORA) e de uma linha específica do Programa Nacional de Agricultura Familiar, o PRONAF Florestal. O PROPFLORA foi lançado em 2002, sob a coordenação do Ministério da Agricultura, Pecuária e Abastecimento (MAPA) no âmbito do Plano Agrícola 2002/2003, visando apoiar pequenos e médios produtores rurais a implantarem e manterem suas "florestas" comerciais ${ }^{42}$ e é operacionalizado pelo Banco do Brasil. Para os produtores familiares, o Ministério do Desenvolvimento Agrário (MDA) estendeu os financiamentos do PRONAF para as atividades "florestais" também em 2002 (MENDES, 2005, p. 16). Em 2003 o Banco do Nordeste passou a fornecer o PRONAF Florestal a mini e pequenos produtores nos estados da Bahia e do Espírito Santo e em 2005 foi criado o Programa BB Florestal $^{43}$ para todo o território nacional (JOLY, 2007, p. 39-40).

\footnotetext{
${ }^{40} \mathrm{O}$ PNF contou com o apoio do projeto FAO/Holanda/UICN/CGP/INT/953/NET - Estratégias e Mecanismos Financeiros para a Conservação e Uso Sustentável das Florestas - Fase I: América Latina, que promoveu estudos sobre o financiamento desta atividade no Brasil (MENDES, 2005, p. 1).

${ }^{41}$ A produção brasileira de base "florestal" associada ao plantio de eucalipto e pinus caracteriza-se por uma grande diversidade de produtos vinculados aos segmentos industriais de papel e celulose, painéis de madeira industrializada, madeira processada mecanicamente, siderurgia a carvão vegetal e biomassa, madeira tratada para construção civil, madeira serrada, entre outros.

42 "Devido ao valor significativo que financia, até $\mathrm{R} \$ 150.000,00$ por ano, com possibilidade de novos empréstimos antes da quitação da dívida, o PROPFLORA tem um público alvo distinto do PRONAF Florestal, formado por produtores rurais com maior poder aquisitivo, bem informados, organizados em cooperativas, com propriedades de tamanho médio normalmente situadas próximas a polos industriais de base florestal" (MENDES, 2005, p. 28).

${ }^{43}$ No primeiro ano do BB Florestal a sua meta de desembolso foi superada em $300 \%$ e o estado de São Paulo recebeu cerca de metade dos recursos liberados (JOLY, 2007, p. 40).
} 
O BB Florestal é um programa de investimento, custeio e comercialização "florestal" mantido pelo Banco do Brasil que visa a implantação e expansão de áreas de silvicultura destinadas ao uso industrial por meio do apoio aos produtores, que atinge de mini e pequenos produtores da agricultura familiar até a agricultura empresarial, passando pelas cooperativas e empresas exportadoras do setor madeireiro. O BB Florestal contempla, entre outros, os programas PROPFLORA e o PRONAF Florestal.

Para o período de 2004 a 2007, o PNF manteve suas estratégias e definiu como meta plantar 500 mil hectares de "florestas" por ano, sendo 200 mil em pequenas e médias propriedades e 300 mil através de programas empresariais (MENDES, 2005, p. 45). Entre 2007 e 2010, o BNDES financiou cerca de 70,9\% de todo o investimento previsto pelos projetos de expansão das principais empresas do setor de papel e celulose, somando R \$ 11,7 bilhões dos R $\$ 20$ bilhões previstos ${ }^{44}$.

Os estados de São Paulo, Bahia, Espírito Santo e Minas Gerais responderam por $80 \%$ das áreas de silvicultura financiadas de forma direta pelo BNDES entre 2001 e 2010. O financiamento do BNDES para a formação de extensos eucaliptais concentrou-se em áreas específicas e privilegiou as unidades industriais com plantio próprio ou as empresas com contrato de fornecimento em longo prazo (FISCHER, 2007).

Além de sua desigual distribuição econômica e geográfica, a concessão do financiamento direto do BNDES para os plantios de pinus e eucalipto ao longo do período entre 2001 e 2010 também se deu de forma desigual, passando de uma participação de $60 \%$ do total financiado nos primeiros cinco anos para $29 \%$, no segundo. Essa redução parece estar relacionada, entre outros fatores, ao desenvolvimento de fontes alternativas de financiamento no período, como os TIMO's e os fundos "florestais" (VIDAL; DA HORA, 2011, p. 150).

Em dezembro de 2014 foi publicado o Decreto $n^{\circ}$ 8375/2014, que estabelece os princípios e objetivos da Política Agrícola de Florestas Plantadas e determina que são atribuições do Ministério da Agricultura, Pecuária e Abastecimento o planejamento e a implementação da mesma. A separação da política nacional de "florestas" plantadas da Política Nacional de Florestas e sua retirada da competência do Ministério do Meio Ambiente vieram atender a uma reivindicação do setor da silvicultura. Contudo, havia a expectativa da realização de adequações institucionais e políticas capazes de eliminar as principais barreiras burocráticas que dificultam o avanço do mercado de produtos "florestais" e de facilitar a participação do investidor nacional e internacional no setor, o que não se concretizou $^{45}$.

\footnotetext{
44 Conforme dados apresentados em notícia disponível em http://www.bndes.gov.br/SiteBNDES/bndes/bndes_pt/Institucional/Sala_de_Imprensa/Noticias/2006/ 20060920_not178_06.html, acessado em: 29 fev. 2012.

45 A Secretaria de Assuntos Estratégicos da Presidência da República (SAE/PR) trabalhou de 2010 a 2014 na formulação do anteprojeto dessa Lei, ouvindo representantes dos setores públicos e privados
} 
A atuação do Estado em apoio ao setor também se expressou em muitos casos por meio de investimento público em infraestrutura de transporte e energia. Porém, de acordo com a Abraf (2013, p. 63-64), a infraestrutura nacional continua deficitária e precária, aumentando muito os custos logísticos no país ${ }^{46}$. Ela ainda destaca o ônus que representam alguns fatores de caráter institucional, que têm criado dificuldades para o setor "florestal", dentre eles são apontados como principais barreiras a serem superadas: a insegurança jurídica gerada com a restrição à compra de terras por estrangeiros ${ }^{47} \mathrm{e}$ a ausência de uma regulamentação sólida sobre o tema; o licenciamento ambiental burocrático, em que o prazo médio da emissão de uma licença para um empreendimento industrial de base "florestal" é de 122 dias; e uma tributação complexa e excessiva.

\section{A empresa Suzano Papel e Celulose}

A Suzano Papel e Celulose se autodefine como "uma empresa de base florestal dedicada aos segmentos de celulose, papel e biotecnologia" e é controlada pela Suzano Holding S. A. ${ }^{48}$ Conforme mencionado anteriormente, ela foi a primeira empresa do setor no Brasil a lançar ações em uma bolsa de valores com a abertura de seu capital em 1980 e também a primeira empresa com plantação de eucalipto a

envolvidos com o tema. Dentre os objetivos esperados para a PNFP, segundo documentos da $\mathrm{SAE} / \mathrm{PR}$, destacavam-se a ampliação de estímulos para a inserção dos pequenos e médios produtores no mercado de "florestas" plantadas e o aperfeiçoamento de estratégias financeiras visando atrair investimentos de origens diversas - o que incluía a criação de um pacote de estímulo ao investimento de fundos de pensão em ativos "florestais" no Brasil; o aprimoramento do seguro rural florestal; e a criação da Cédula de Crédito Florestal. A Cédula de Crédito Florestal (CCF) seria um título de investimento melhor ajustado ao longo ciclo da silvicultura do que a Cédula de Produto Rural (CPR) e assim poderia dar ao investidor nacional e internacional maior segurança para participar do negócio "florestal" (SAE, 2013). A CPR é um título que atende hoje à produção agrícola em geral, ele é representativo do que será produzido, com qualidade e quantidade especificadas, acompanhado de um contrato de venda e pode ser caracterizado como CPR Física quando sua liquidação é feita em produto. O produtor rural emite a CPR para o fundo financeiro, o qual oferece ao produtor um adiantamento para a implantação do projeto e negocia a CPR com a empresa interessada em adquirir o produto agrícola em questão (MENDES, 2005, p. 39-40).

${ }^{46}$ De acordo com a Abraf, "nos Estados Unidos, o custo logístico médio para transportar uma tonelada de celulose ao porto é de aproximadamente US\$20. No Brasil, o desembolso com esse componente pode chegar a US\$90" (ABRAF, 2013, p. 63).

47 Conforme Parecer $n^{\circ} 1 / 2008$ da Controladoria Geral da União (CGU), publicado em outubro de 2010.

${ }^{48}$ A Suzano Holding, criada em 2003, também controla negócios na área de distribuição de produtos gráficos, seguros, mercado imobiliário, serviços ambientais e pretende se estabelecer na área de energia renovável. Em 2009 foi criada a MDS consultores de Seguros e Risco a partir de uma joint venture entre a Suzano e o grupo português Sonae e, em 2010, foi criada a Alden Desenvolvimento Imobiliário em joint venture com a Helbor Empreendimentos Imobiliários. O grupo mantém escritórios comerciais na China, nos Estados Unidos e na Suíça, laboratórios de pesquisa em Israel e na China e subsidiárias na Inglaterra (Sun Paper) e na Argentina (Stenfar) (SUZANO, 2012b, p. 11). 
vender crédito de carbono na Chicago Climate Exchange em 2004. Mais tarde, em 2011, inovou novamente na área ambiental e foi a primeira empresa de papel e celulose do mundo a quantificar sua pegada de carbono.

Ela é uma empresa verticalizada, ou seja, desenvolve todas as etapas do processo produtivo de forma integrada, desde a pesquisa e experimentação de espécies e variedades mais produtivas, a produção da muda em viveiros, o plantio e manejo do eucalipto, a colheita e o transporte, até a produção da celulose e do papel e sua distribuição. Nas etapas relativas à produção de eucalipto ela tem contratado de forma crescente o serviço de empresas terceirizadas para a realização de diversas atividades como produção de mudas, plantio e colheita de eucalipto ${ }^{4}{ }^{\circ}$.

Do ponto de vista da gestão, a Suzano está dividida em três Unidades de Negócio distintas, a "Florestal", a de Celulose e a de Papel. Cada uma delas, além de atender aos interesses da produção integrada, busca realizar negócios com outras empresas e mercados (SUZANO, 2009).

A Suzano foi pioneira no plantio de eucalipto para a produção de celulose no país. Nos anos 1950, após o investimento em pesquisa, ela começa a produzir celulose de eucalipto em São Paulo para o seu abastecimento em substituição à celulose de pinus importada, tornando-se em pouco tempo uma empresa de destaque no mercado nacional.

Nos anos 1980, a Suzano investe na criação da Bahia Sul Celulose, em Mucuri (BA), visando expandir tanto a produção de papel como a exportação de celulose. Esta empresa surgiu da associação ou joint venture ${ }^{50}$ entre as seguintes empresas, conforme sua participação: Suzano $(37,77 \%)$, Companhia Vale do Rio Doce ${ }^{51}$ $\left(30,91 \%\right.$, através da Florestas Rio Doce), BNDESpar ${ }^{52}(27,66 \%)$ e Corporação Financeira Internacional $^{53}$ (3,66\%) (MONTEBELLO, 2006, p. 20; JUVENAL e MATTOS, 2002, p. 15). Chama atenção a importância da participação do setor público nesta joint venture; além do BNDESPar e da CVRD, o IFC também é

\footnotetext{
${ }^{49}$ Conforme a legislação em vigor essa situação configura uma irregularidade, pois uma empresa não pode contratar prestadores de serviço para funções ligadas à sua atividade-fim. A Suzano foi acionada pelo Ministério Público do Trabalho (MPT) por prática de terceirização ilegal em sua unidade de Mucuri (BA) e foi condenada a pagar uma multa de R $\$ 2$ milhões em indenização por dano moral coletivo em 12 de julho de 2013 (O Estado de São Paulo, 12/07/2013). Atualmente tramita no Congresso o Projeto de Lei $n^{\circ} 4.330$, que visa regulamentar o trabalho terceirizado no país e propõe várias medidas no sentido de uma maior liberalização desta prática, inclusive com a permissão da terceirização de atividades-fim das empresas do setor privado.

${ }^{50}$ União de duas ou mais empresas já existentes com o objetivo de iniciar ou realizar uma atividade econômica específica.

${ }^{51}$ Atualmente sua razão social é Vale S.A e desde 2007 utiliza o nome fantasia Vale. A empresa é uma das maiores mineradoras do mundo.

52 BNDESpar é a sociedade gestora de participações sociais (holding) do BNDES, criada para administrar as participações em empresas detidas pelo banco.

53 A Corporação Financeira Internacional (CFI) é uma subsidiária do Banco Mundial para financiamento do setor privado e apoia outros projetos de empresas brasileiras no setor. Em parceria com investidores privados, a IFC proporciona tanto empréstimos quanto participação acionária em negócios nos países em desenvolvimento (INTERNATIONAL FINANCE CORPORATION, 2014).
} 
constituído em grande parte por recursos públicos, ou seja, recursos oriundos dos países membros do Banco Mundial. Os três sócios juntos somam uma participação de $62,23 \%$ no empreendimento.

Em 2001 a Suzano adquiriu a parte da CVRD na Bahia Sul Celulose, que passou a se chamar Suzano Bahia Sul. A gestão das duas empresas, Suzano e Bahia Sul, foi unificada quando criada a Suzano Papel e Celulose, com sede na Bahia.

Em 2003 a linha de celulose da Suzano foi ampliada e passou a contar com capacidade de produção de mais $100 \mathrm{mil}$ ton/ano e, no ano seguinte, houve o acréscimo de 43 mil ton/ano de papel. Em 2004 foi concluída a otimização da planta de celulose em Mucuri (BA), que atingiu 645 mil ton/ano de capacidade total de celulose.

Ainda no ano de 2004, a Suzano e a Votorantim Celulose e Papel formaram um consórcio que arrematou a totalidade das ações da Ripasa no município de Limeira (SP) e passou a se denominar Consórcio Paulista de Papel e Celulose (Conpacel), seis anos depois a Suzano comprou a parte da Votorantim e tornou-se proprietária da totalidade da Conpacel. Em 2007 foi concluída a aquisição pela Suzano de uma fábrica de produção de papel cartão no Embu (SP) e a Linha 2 da unidade em Mucuri (BA) iniciou sua produção.

Em 2008 a Suzano anuncia um ambicioso plano de crescimento que prevê a ampliação da unidade de produção em Mucuri e a instalação de indústrias de celulose no Maranhão e no Piauí, que surgem como um novo lócus para a territorialização de investimentos em larga escala da empresa. Em dezembro de 2013, a fábrica de Imperatriz (MA) iniciou suas atividades, mas o projeto da fábrica do Piauí não se concretizou, sobretudo devido ao elevado nível de endividamento da empresa e à retração do mercado decorrente da crise econômica mundial.

Como apoio do Estado para o empreendimento da fábrica de Imperatriz, destacam-se o financiamento do BNDES de R \$ 2,7 bilhões, com prazo de 12 anos para pagamento e 3 anos de carência; e incentivos fiscais de redução de $75 \%$ da alíquota de imposto de renda pelo período de 10 anos e depreciação acelerada incentivada (DAI) do imobilizado ${ }^{54}$ conforme Leis $\mathrm{n}^{\circ} 11.196$ e $\mathrm{n}^{\circ} 12.712$, esta última sancionada em agosto de 2012 (SUZANO, 2012a, p. 14).

O impressionante desempenho da Suzano nos anos 2000 se valeu da continuidade do amplo apoio do Estado brasileiro - agente financeiro fundamental no processo de reestruturação das empresas do setor - e de uma evolução favorável do mercado internacional, especialmente até a crise de 2008. Porém, o início da segunda década do século XXI tem exigido da Suzano a redução do grau de

\footnotetext{
${ }^{54}$ A DAI consiste na redução ou diferimento do pagamento de imposto e contribuições, de forma isolada ou conjunta (Disponível em: http://www.portaltributario.com.br/tributario/depreciacaoacelerada.html. Acessado em: 06 nov. 2015).
} 
alavancagem $^{55}$ da empresa e o adiamento de novos projetos. Seus megainvestimentos somados aos de seus principais concorrentes nacionais e internacionais já delineiam um cenário de possível excesso de oferta em face de um mercado consumidor em retração. Os desdobramentos da crise econômica mundial ainda são sentidos pelo mundo de diversas formas, afetando importantes mercados consumidores para os produtos da Suzano.

\begin{tabular}{llllll}
\hline \multicolumn{1}{c}{ Unidade } & \multicolumn{2}{c}{ Celulose } & \multicolumn{2}{c}{ Papel } \\
\hline (mil ton.) & Integrada & $\begin{array}{c}\text { Celulose } \\
\text { de } \\
\text { Mercado }\end{array}$ & $\begin{array}{c}\text { Não } \\
\text { Revestidos }\end{array}$ & Revestidos & $\begin{array}{c}\text { Papel } \\
\text { Cartão }\end{array}$ \\
Maranhão & - & 1.500 & - & - & - \\
Mucuri & 200 & 1.540 & 250 & - & - \\
Suzano & 460 & 40 & 270 & 90 & 200 \\
Limeira & 310 & 340 & 280 & 100 & - \\
Rio Verde & - & - & 50 & - & - \\
Embu & - & - & - & - & 50 \\
Total & 970 & 3.420 & 850 & 190 & 250 \\
\hline
\end{tabular}

Tabela 1: Produção por unidade industrial da Suzano.

Fonte: Suzano, 2013. Disponível em: http://ri.suzano.com.br/static/ptb/capacidade-deproducao.asp?language=ptb. Acessado em 22 jan. 2014.

Nota: A Unidade Maranhão, em Imperatriz (MA), iniciou suas atividades em dezembro de 2013. Em 2014 estimava-se uma produção de 1.150 mil toneladas de celulose. Em 2015 espera-se que a Unidade Maranhão produza sua capacidade nominal de 1.500 mil toneladas.

Em 2012, a Suzano comercializou 1.900 mil toneladas de celulose com 31 países, sendo 32\% destinadas à Europa, 36\% à Ásia, 2\% à América Latina (excluindo o Brasil), 22\% ao Brasil e $8 \%$ à América do Norte. Com o início das operações no Maranhão em 2013, sua produção de celulose de mercado deverá alcançar cerca de 3.400 mil toneladas (ver Tabela 1), o que representará uma expansão significativa das suas exportações ${ }^{56}$.

As vendas de papel alcançaram o volume de 1.290 mil ton em 2012. Desse total, 66,4\% foram distribuídos no Brasil, 15\% na América do Sul/Central, 9,9\% na América do Norte e 5,8\% na Europa. Sua produção de papel é vendida em mais de 60 países.

As receitas provenientes dos segmentos de papel e de celulose corresponderam a $58 \%$ e $42 \%$ respectivamente em 2012, sendo o mercado interno o principal destino da produção de papel e o mercado externo prevalentemente o da celulose. As

\footnotetext{
${ }^{55}$ Em finanças alavancagem é o termo utilizado para qualquer técnica aplicada para multiplicar a rentabilidade por meio de endividamento. $\mathrm{O}$ incremento proporcionado pela alavancagem aumenta os riscos da operação e a possibilidade de insolvência.

${ }^{56}$ Ver Relatórios de Sustentabilidade da Suzano de 2004, 2008 e 2012 no site Suzano Relações com Investidores.
} 
vendas no mercado nacional respondem por $48 \%$ da receita líquida, enquanto as vendas no mercado externo correspondem a $52 \%$ desta.

A expansão da empresa nos últimos anos se reflete no volume de mão de obra empregada, que alcança a cifra de 6,8 mil trabalhadores contratados e 9,6 mil terceirizados em 2012, enquanto em 2008 eram 3,7 mil contratados (SUZANO, 2012b, p.11). Chama atenção o elevado número de trabalhadores terceirizados em grande parte empregados na produção "florestal", atividade-fim da empresa.

O crescimento da produção também está relacionado à seleção de plantas melhor adaptadas às condições edafoclimáticas de cada região onde a Suzano atua, com elevados ganhos de produtividade ${ }^{57}$ e à ampliação de sua base "florestal". A isso se deve a sua expansão pelo extremo sul da Bahia e no Espírito Santo, além da ocupação de áreas nos estados do Maranhão, Piauí e Tocantins em seu novo ciclo de crescimento.

${ }^{57}$ A produtividade média alcançada nos plantios da Suzano é de 41,6 m3/hectare/ano (SUZANO, 2013b). 


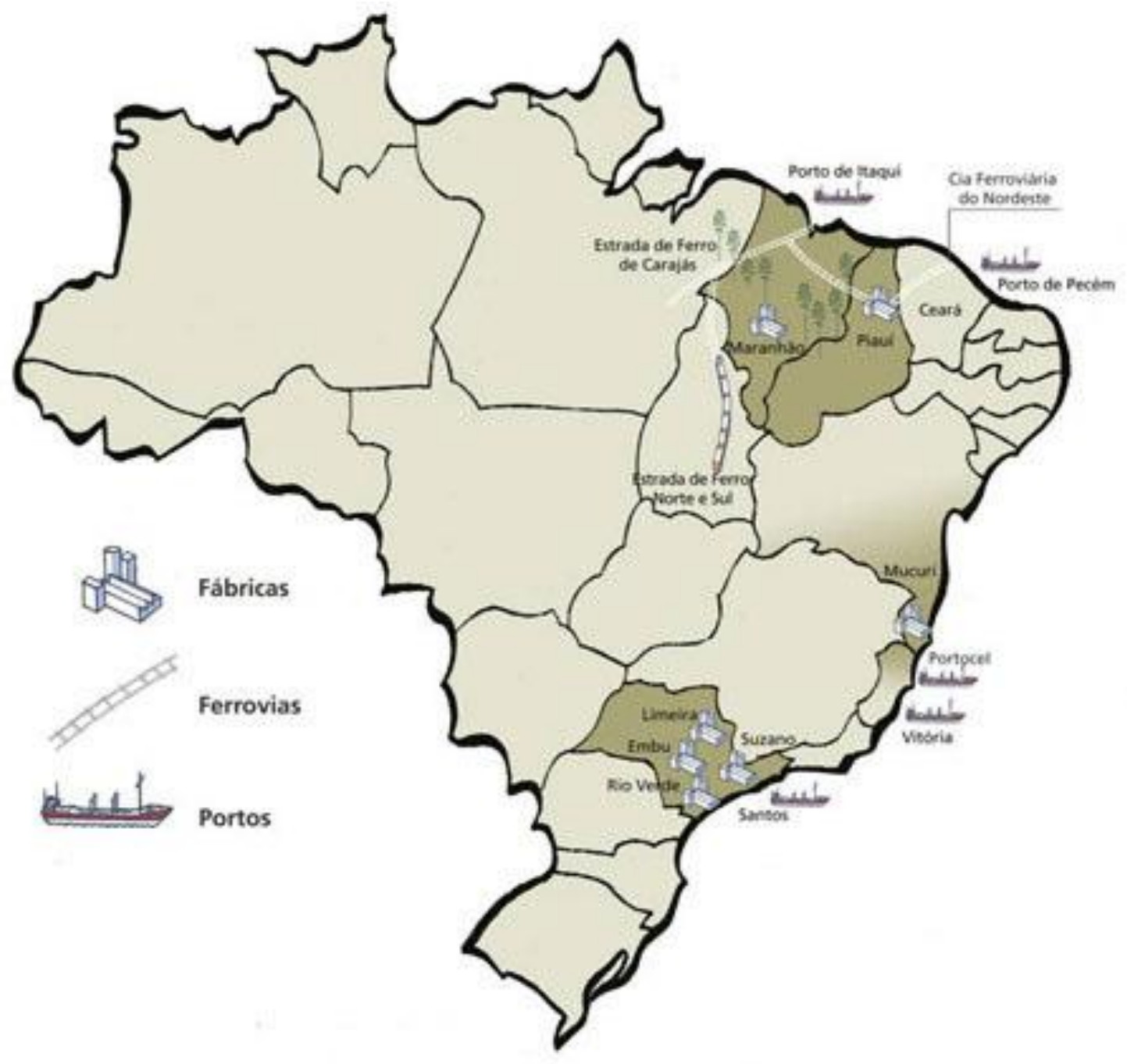

Figura 1: Distribuição territorial da Suzano no Brasil.

Fonte: SUZANO. (2010). Disponível em: www.suzano.com.br. Acesso em: 29 de nov. de 2010.

A Suzano concentra suas principais atividades em três regiões, nucleadas a partir de suas unidades industriais que estão distribuídas nos estados de São Paulo, Bahia e Maranhão. A sua territorialização em regiões distintas do país, caracterizadas por grandes diferenças quanto à economia, infraestrutura, localização, cultura e meio ambiente, confere à Suzano uma maior flexibilidade para lidar com os riscos e desafios característicos de suas atividades.

Em São Paulo ela disputa com outras empresas a produção proveniente de uma grande diversidade de municípios, tendo como um de seus principais centros a mesorregião de Itapetininga que, juntamente com a de Bauru, é responsável por 
cerca de metade da produção de eucalipto do estado. ${ }^{58}$ No caso da unidade de Mucuri, na Bahia, a Suzano divide com a Fibria o controle do extremo sul do estado - caracterizado por um elevado grau de especialização produtiva, onde está condensada cerca de $87 \%$ dos eucaliptais baianos -, além de áreas no Espírito Santo e Minas Gerais. No Maranhão, por sua vez, a Suzano não tem concorrentes importantes na área em que atua e sua matéria-prima provém de plantios situados no estado e também no Pará, Piauí e Tocantins.

Sua base "florestal" em 2012 abrangia aproximadamente 819 mil ha de terras, distribuídos pelos estados acima mencionados. Desse total, cerca de $442 \mathrm{mil}$ ha eram destinados aos plantios de eucalipto e 296 mil ha, à preservação ambiental, como mostra a Tabela 2.

\begin{tabular}{llll}
\hline \multicolumn{1}{c}{ Ativos Florestais } & \multicolumn{3}{c}{ Anos } \\
\hline \multicolumn{1}{c}{$($ mil ha) } & 2004 & 2008 & 2012 \\
Área total $^{1}$ & $498^{3}$ & 570 & 819 \\
Área plantada total $^{2}$ & 310 & $364^{3}$ & 442 \\
Área própria plantada $^{1}$ & 254 & 271 & 354 \\
Parceria Florestal $_{\text {Área de preservação própria }}{ }^{1}$ & 56 & 93 & $88^{3}$ \\
\hline
\end{tabular}

Tabela 2: Ativos "florestais" da Suzano nos anos 2004, 2008 e 2012.

Fonte: SUZANO, Relatórios de Sustentabilidade de 2004, 2008 e 2012. Disponível em: http://ri.suzano.com.br/ptb/s-4-ptb.html.

1 Área própria e áreas arrendadas.

2 Considera áreas próprias, arrendadas e fomento.

${ }^{3}$ Valor aproximado, calculado a partir de dados apresentados nos relatórios de sustentabilidade e no site da empresa.

Nota: Segundo a Suzano, áreas próprias e arrendadas podem sofrer variações de até $5 \%$ de um trimestre para o outro e os somatórios podem divergir devido a arredondamentos.

A Suzano produz a maior parte da matéria-prima de que precisa a partir de terras sob sua administração direta, que define como "terras próprias". Essas terras podem ser de propriedade da empresa ou arrendadas ${ }^{59}$ num processo de territorialização do capital aliado à monopolização do território, caracterizado pela formação de extensas áreas sob o seu controle, distribuídas nas três regiões indicadas.

As terras de sua propriedade têm sido adquiridas por meios diversos, o que inclui o uso de empresas subsidiárias, como é o caso da Comercial Agrícola Paineiras Ltda., que atua no Leste Maranhense com a compra de terras e

\footnotetext{
${ }^{58}$ As duas mesorregiões somavam uma produção de mais de 10 milhões de $\mathrm{m}^{3}$ de madeira em 2012 (IBGE, 2012).

${ }^{59} \mathrm{O}$ arrendamento feito pela Suzano para o plantio de eucalipto em geral se estende por um período de 14 anos ou dois ciclos produtivos. Não foi encontrada em nenhum documento da empresa a informação sobre o total de terras de propriedade da Suzano em separado da quantidade de terras arrendadas, o que dificulta uma avaliação mais precisa de suas estratégias fundiárias.
} 
implantação da monocultura de eucalipto (PAULA ANDRADE et al., 2012, p. $26)^{60}$. Também arrenda terras, principalmente na área de abastecimento da Unidade de Limeira no estado de São Paulo. Isso se deve a dois motivos: ao fato de que durante o período em que a fábrica de Limeira pertencia à Suzano em sociedade com a Votorantim se optou por não realizar investimentos na compra de terras; e também à necessidade de redução do impacto nas contas da empresa do alto preço da terra praticado na região.

Como estratégia complementar de aprovisionamento, a Suzano compra madeira produzida por outras duas maneiras, seja valendo-se de negócios com empresas gestoras de fundos "florestais" - que investem capital de terceiros no campo, numa territorialização do capital em que a mediação do financeiro desempenha um papel central e dá sentido ao processo -; seja por meio de programas de fomento, que integram propriedades próximas às suas fábricas, configurando uma situação de monopolização do território pelo capital ${ }^{61}$. O fomento tem sido uma estratégia mais utilizada do que o recurso às TIMO's.

Essas estratégias têm ganhado maior importância principalmente devido ao aumento do preço das terras em decorrência da expansão do setor "florestal" - além de outros segmentos do agronegócio - e à necessidade de investimentos cada vez maiores para a implantação e modernização de unidades industriais no setor de papel e celulose. Em 2009 a Suzano fechou um acordo com a Vale Florestar para a compra de madeira de uma área de 50 mil ha no Pará, voltada ao abastecimento de sua fábrica em Imperatriz no período de 2014 a 2028. Além disso, foi efetuada a compra de 84,7 mil ha de terras da Vale, dos quais 34,5 mil ha com plantios de eucaliptos no Maranhão ${ }^{62}$.

A compra e venda de eucaliptais é uma prática que existe há algum tempo no setor de produção de madeira. A própria Suzano tem se valido dela em diferentes ocasiões, como no caso da venda de terras e eucaliptais da empresa em Minas Gerais em 2009, com o intuito de reduzir o grau de alavancagem da empresa (SUZANO-RELAÇÕES COM INVESTIDORES, 2014). A novidade agora é que os negócios com ativos "florestais" têm envolvido de forma direta mecanismos e atores do mercado financeiro, como é o caso da Vale Florestar.

A Suzano denomina o seu programa de fomento de Programa de Parceria Florestal. Ele engloba produtores de pequeno, médio e grande porte; e sua área de abrangência inclui os estados da Bahia, Maranhão, Piauí e São Paulo. A empresa iniciou a atividade de fomento em São Paulo com o fornecimento de mudas e

\footnotetext{
60 Em várias comunidades de posseiros visitadas na região ouvimos denúncias de grilagem envolvendo a Paineiras.

${ }^{61}$ Nos termos expostos por Oliveira (1999), em sua teoria sobre as transformações territoriais decorrentes do desenvolvimento do capitalismo no campo.

${ }^{62}$ Os negócios da Suzano com a Vale estão relacionados com a existência de um polo de reflorestamento na região que engloba o Pará e o Maranhão, criado com amplo apoio do Estado com o objetivo de abastecer de carvão vegetal as guseiras aí instaladas e em decorrência do Projeto Grande Carajás (VALOR ECONÔMICO, 14/07/2009).
} 
assistência técnica em 1973. Mas a prática do fomento contratual só teve início em 1992, na Bahia, estendendo-se para São Paulo em 2002 e para o Maranhão e o Piauí a partir de 2010. Os fomentados da Suzano em São Paulo estão situados numa distância média de até $200 \mathrm{~km}$ em relação à unidade industrial, enquanto a distância ideal considerada deve ser inferior a $100 \mathrm{~km}$, como ocorre com os fomentados na Bahia (MENDES, 2005).

O Programa de Parceria Florestal se encontra dividido em duas modalidades, a Renda Verde - para proprietários com até 15 módulos rurais - e a Invest Verde, para propriedades maiores. O Invest Verde foi criado em 2005 e inclui o fornecimento de mudas de eucalipto, assistência técnica e croqui da área plantada pela Suzano. Ele supõe um contrato de compra e venda de madeira em que o produtor se compromete a implantar a cultura com recursos próprios, atendendo às orientações técnicas da empresa, e a vender no mínimo $50 \%$ da madeira produzida ao preço de mercado na ocasião da colheita (SUZANO, 2013a).

No Renda Verde, além do fornecimento de mudas de eucalipto e da assistência técnica, alguns recursos são financiados pela Suzano - como adubos, herbicidas, formicida e também custos com serviços de plantio e tratos culturais. É estabelecido um contrato de compra e venda de madeira no qual o produtor compromete-se a vender $95 \%$ de sua produção à Suzano, podendo utilizar os $5 \%$ restantes para outros fins. Os valores adiantados a título de financiamento (précompras de madeira) são convertidos em volumes de madeira que serão pagos com parte da produção obtida na primeira colheita, tomando-se como base o preço praticado pelo mercado na ocasião da entrega do produto (SUZANO, 2013a).

A Suzano tem proporcionado o acesso a linhas de crédito para esse último segmento de produtor integrado por meio de convênios com o Banco do Brasil e o Banco do Nordeste do Brasil, em que atua como avalista ${ }^{63}$ e faz a intermediação na transação. $O$ produtor firma o contrato de financiamento e também o contrato de fomento com a Suzano e, por meio da venda da madeira, paga ao Banco pelo financiamento (SECRETARIA DE ASSUNTOS ESTRATÉGICOS DA PRESIDÊNCIA DA REPÚBLICA, 2011, p. 37). Desta forma, a empresa aumenta o seu controle sobre os produtores fomentados e, como destaca Mendes, minimiza a resistência apresentada pelos agentes financeiros a conceder financiamentos para este setor, uma vez que os produtores geralmente não dispõem de patrimônio suficiente para garantir mais de um empréstimo de longo prazo (2005, p. 28 e 42).

$\mathrm{O}$ fomento constitui um tipo de parceria e pode ser entendido como um arrendamento disfarçado, pelo fato de os vários momentos da produção serem controlados pela Suzano não restando ao produtor autonomia para gerir a cultura que realiza em sua propriedade. $\mathrm{O}$ fomento pode representar uma vantagem para a

\footnotetext{
${ }^{63} \mathrm{O}$ papel de avalista do produtor florestal junto às instituições financeiras, para a tomada por este de financiamentos para investimento florestal, também é desempenhado por outras empresas dos segmentos de celulose e papel, painéis de madeira e madeira serrada (SECRETARIA DE ASSUNTOS ESTRATÉGICOS DA PRESIDÊNCIA DA REPÚBLICA, 2011, p. 37).
} 
empresa, no sentido de reduzir o valor por ela pago ao proprietário como renda da terra e os riscos que um acerto prévio de preço pelo aluguel da terra, como ocorre com o arrendamento, pode gerar.

Há diferenças regionais importantes entre os mercados de terra e de madeira nos estados onde a Suzano se territorializa. Chama a atenção o fato de em São Paulo, onde há maior demanda por terra, o arrendamento ser a estratégia complementar mais importante adotada por empresas de base "florestal" ${ }^{64}$, correspondendo a $24,4 \%$ da área plantada, enquanto na Bahia é o fomento que alcança cerca de 25,3\% da área plantada (ABRAF, 2013, p. 51).

Quanto mais a produção de celulose da Suzano ganha espaço no mercado internacional, mais a empresa amplia a sua territorialização no país, controlando imensas áreas de monocultura de árvores, impactando - em extensão e profundidade - a economia, a política, o meio ambiente, a cultura, enfim, a vida em um grande número de municípios nas regiões em que atua. Ora sua base "florestal" é criada por meio do recurso ao desmatamento em larga escala, muitas vezes com o uso ilegal do correntão em áreas de mata atlântica e de cerrado que eram comumente utilizadas por comunidades locais que viviam do agroextrativismo. Ora seus plantios se instalam em áreas já desmatadas e degradadas que enfrentam uma situação de crise, desencadeando um processo de conversão produtiva.

Os eucaliptais são grandes consumidores de água, afetando geralmente os recursos hídricos disponíveis nas áreas em que são plantados. Comunidades vizinhas se queixam da redução do volume de água de córregos e rios, inclusive com prejuízo para quem vive da pesca devido à diminuição da quantidade de peixes encontrada nesses cursos d'água. Outra queixa recorrente é quanto ao uso excessivo de agrotóxicos como formicidas e herbicidas e à contaminação das águas. Também foram ouvidas denúncias quanto à prática de descarga de efluentes das unidades de processamento nos cursos d'água, como é frequente no Rio Mucuri, na Bahia.

\section{Considerações Finais}

Este artigo analisou aspectos da expansão recente verificada no setor de papel e celulose no Brasil, evidenciando que a estruturação e territorialização de grandes empresas mundiais, como a Suzano, têm contado historicamente com a efetiva atuação do Estado por meio de políticas de apoio à silvicultura e à indústria, além de ações no sentido de assegurar as condições institucionais e de infraestrutura necessárias.

\footnotetext{
${ }^{64}$ Esta realidade também é influenciada pelo fato de a International Paper possuir extensas áreas arrendadas em São Paulo por se tratar de empresa estrangeira e, por isso, estar impedida de possuir terras numa extensão superior a um quarto da superfície dos municípios onde se situa.
} 
De um lado, observa-se um grande dinamismo na indústria de papel e celulose no sentido da concentração e centralização de capitais, com inúmeros casos de fusão e aquisição. De outro, a produção de espaços marcados pela presença de extensos eucaliptais, em detrimento de outras formas de ocupação. São constituídas paisagens rurais homogeneizadas, expressão do denominado "deserto verde" - um campo esvaziado da presença humana e de animais.

A análise da trajetória da Suzano nos revela que o autoabastecimento continua a ser a principal estratégia para a obtenção da madeira, assim como ocorre nas demais empresas do setor, caracterizado pela produção integrada. Entretanto, observou-se uma variedade de outras estratégias empregadas para a aquisição da matéria-prima que têm assumido importância crescente, como o fomento e os contratos realizados com grandes produtores independentes e gestores de investimentos "florestais" - as TIMO's.

Todas essas mudanças se dão juntamente com a formação de mercados regionais de madeira, terras e trabalho, relacionados ao processo produtivo e conectados a outros mercados em nível nacional e mundial, como o de papel, celulose e de capitais. Destaca-se aqui a novidade da inserção do país no mercado global de ativos "florestais", que conta com a participação de investidores como fundos de pensão, companhias de seguro, fundações e fundos patrimoniais, representando o avanço da financeirização sobre o negócio "florestal".

\section{Bibliografia}

ABRAF. (2013) Anuário estatístico ABRAF 2013. Brasília: ABRAF. Disponível em: <http://www.abraflor.org.br/estatisticas/ABRAF13/ABRAF13_BR.pdf>. Acessado em: $20 \mathrm{dez} .2014$.

BIAZUS, A. et al. (2010a) O potencial de investimento nos setores florestal de celulose e de papel. In: TORRES, Ernani et al. (orgs.) Perspectivas do Investimento: 2010-2013. Rio de Janeiro: BNDES. Disponível em: http://www.bndes.gov.br/SiteBNDES/export/sites/default/bndes_pt/Galerias/Arqui vos/conhecimento/liv_perspectivas/04_Perspectivas_do_Investimento_2010_13_P APEL_E_CELULOSE.pdf. Acessado em: 20 nov. 2014. . (2010b) Panorama de mercado: celulose. BNDES Setorial 32, set 2010.

pp. 311-370. Rio de Janeiro: BNDES. Disponível em: https://web.bndes.gov.br/bib/jspui/handle/1408/1312. Acessado em: 17 jan. 2014. BRACELPA. (2013) Dados do Setor - dezembro de 2013. São Paulo: Bracelpa. Disponível em: http://www.bracelpa.org.br/bra2/sites/default/files/estatisticas/ booklet.pdf. Acessado: em 02 jan. 2014.

BRACELPA. (2014) Dados do Setor - março de 2014. São Paulo: Bracelpa. Disponível em: 
http://bracelpa.org.br/bra2/sites/default/files/estatisticas/booklet.pdf $>$. Acessado em: 02 jun. 2015.

CHESNAIS, F. (org.). (1996) La mondialization financière: genèse, coût et enjeux. Paris: Syros. (Alternatives économiques)

COSTA, F. N. da (2012). Anatomia da Crise USA (Unibanco-Sadia-Aracruz) em 2008, 21/12/2012,

Disponível

em

https://fernandonogueiracosta.wordpress.com/2012/12/21/anatomia-da-crise-daaracruz-em-2008/. Acessado em: 07 nov. 2015.

GAZETA MERCANTIL. (2009) Florestas brasileiras atraem interesse de fundos estrangeiros. 04/03/2009. Agência Brasileira de Inteligência [online]. Disponível em: http://www.abin.gov.br/modules/articles/article.php?id=4011. Acessado em 10 mar. 2013.

FISCHER, A. (2007) Incentivos em programas de fomento florestal na indústria de celulose. 260 f. Tese (Doutorado em Administração) - Faculdade de Economia, Administração e Contabilidade, Universidade de São Paulo. São Paulo.

HARVEY, David. (2004) O novo imperialismo. São Paulo: Ed. Loyola.

JOLY, C. (2007) Especialização produtiva do território e o circuito espacial produtivo de celulose em Eunápolis - BA. 98f. Dissertação (Mestrado em Geografia Humana) - Faculdade de Filosofia, Letras e Ciências Humanas, Universidade de São Paulo. São Paulo.

JUVENAL, T. L.; MATTOS, R. L. G. (2002) O Setor de Papel e Celulose no Brasil. BNDES. Disponível em <http://www.bndes.gov.br/SiteBNDES/export/sites/default/ bndes_pt/Galerias/Arquivos/conhecimento/livro_setorial/setorial04.pdf >. Acessado em 12 dez 2013.

MENDES, J. (2004) Incentivos e mencanismos financeiros para o manejo florestal sustentável na Região Sul do Brasil. Curitiba: Relatório 03 FAO 01 - Mecanismos Financeiros. Disponível em: <http://www.fao.org/forestry/1200009ec4e1c04ebfcd232f76c89136cadcf.pdf>. Acessado em 03 jan. 2014.

. (2005) Estratégias e mecanismos financeiros para florestas plantadas. Curitiba, Relatório FAO. Disponível em: <http://www.fao.org/forestry/1207506238d2267638fe1c5a6f26abaa6fb6ef.pdf>. Acessado em 03 jan. 2014.

MONTEBELLO, A. E. S. (2006) Análise da evolução da indústria brasileira de celulose no período de 1980 a 2005. 102f. Dissertação (Mestrado em Ciências) Escola Superior de Agricultura Luiz de Queiroz, Universidade de São Paulo. Piracicaba.

. (2010) Configuração, reestruturação e mercado de trabalho do setor de celulose e papel no Brasil. 172f. Tese (Doutorado em Ciências) - Escola Superior de Agricultura Luiz de Queiroz, Universidade de São Paulo. Piracicaba.

OLIVEIRA, A. U. de. (1999) A geografia agrária e as transformações territoriais recentes no campo brasileiro. In: Carlos, Ana F. A. (org.). Novos caminhos da geografia. São Paulo: Contexto. 
PAULA ANDRADE, M. de et al. (2012) Conflitos socioambientais no Leste Maranhense: problemas provocados pela atuação da Suzano Papel e Celulose e dos chamados gaúchos no Baixo Parnaíba. 231f. Relatório de pesquisa - Grupo de Estudos Rurais e Urbanos, Universidade Federal do Maranhão, São Luís.

SECRETARIA DE ASSUNTOS ESTRATÉGICOS DA PRESIDÊNCIA DA REPÚBLICA. (2011) Diretrizes para a estruturação de uma Política Nacional de Florestas Plantadas. (Grupo de Trabalho Interministerial Portaria SAE/PR no 90 de 20/08/2010). Disponível em: <http://www.faeb.org.br/fileadmin/Arquivos_ internos/Cadeia_Florestal/Politica_Nacional_de_Florestas_Plantadas_31-032011.pdf>. Acessado em 12 jan. 2014.

SILVA, B. K. da. (2013) Investimentos em ativos florestais no Brasil: estratégias dos investidores e perspectivas econômicas. 151f. Dissertação (Mestrado em Recursos Florestais) - Escola Superior de Agricultura Luiz de Queiroz, Universidade de São Paulo. Piracicaba.

SUZANO. (2009) Resumo público - São Paulo, Plano de manejo florestal, 2009. São Paulo, 2009. Disponível em: <http://www.suzano.com.br/portal/suzano-papele-celulose/plano-de-manejo.htm>. Acessado em: 02 ago. 2011.

. (2011) Resumo público-Maranhão e Tocantins, Plano de manejo florestal, 2011. Disponível em: <http://www.suzano.com.br/portal/suzano-papel-ecelulose/plano-de-manejo.htm>. Acessado em: 10 mar. 2012.

(2012a) Release de Resultados4T12. Disponível em http://v4.suzano.infoinvest.com.br/fck_temp/mala_direta/file/Release\%20de\%20R esultados\%204T12_final-na.pdf. Acessado em: 11 nov. 2015.

(2012b) Relatório de Sustentabilidade 2012. Disponível em : http://suzano.infoinvest.com.br/ptb/4567/RELATRIODESUSTENTABILIDADE2 012.pdf. Acessado em: 22 out. 2013.

(2013a) Resumo público - São Paulo, Plano de Manejo Florestal, 2013.Disponível em: <http://www.suzano.com.br/portal/suzano-papel-ecelulose/plano-de-manejo.htm>. Acessado em: 20 out. 2013.

(2013b) Unidade de Negócio Florestal. Disponível em: http://www.suzano.com.br/portal/suzano-papel-e-celulose/unidade-de-negocioflorestal.htm.Acesso em 20 out 2013.

UNFF. (2012) 2012 Study on Forest Financing. Disponível em: http://www.un.org/esa/forests/pdf/AGF_Study_July_2012.pdf. Acessado em: 10 jan. 2015.

VIDAL, A.; DA HORA, A. (2011) A atuação do BNDES nos setores de florestas plantadas, painéis de madeira, celulose e papéis: o período 2001-2010. BNDES Setorial 34. pp. 133-172. Rio de Janeiro: BNDES.

. (s/d) A indústria de papel e celulose. Brasília, BNDES. Disponível em: http://www.bndes.gov.br/SiteBNDES/bndes/bndes_pt/Institucional/Publicacoes/Co nsulta_Expressa/Tipo/BNDES_Setorial/201210_9.html, acesso em 10/08/2013) 
WHITEMAN, A. (2005) Recent trends and developments in global markets for pulp and paper. Rome: Organization of the United Nations. Disponível em: ftp://ftp.fao.org/docrep/fao/008/af303e/af303e00.pdf. Acessado em: 20 abr. 2015. WORLD RAINFOREST MOVEMENT. (2013) Velhos e novos investidores por detrás da expansão dos monocultivos de árvores. Boletim Mensal WRM, 191, jun 2013. pp. 3-9. Disponível em: 〈http://wrm.org.uy/pt/files/2013/06/Boletim191.pdf>. Acessado em:30 ago. 2013.

\section{Sites consultados}

BRASIL ECONÔMICO. Disponível em: http://www.brasileconomico.com.br/. Acessado em: 08 jan. 2014.

IBGE - INSTITUTO BRASILEIRO DE GEOGRAFIA E ESTATÍSTICA. Disponível em: http://www.ibge.gov.br/home/. Acessado em: diversas datas entre mar. de 2012 e dez. de 2013.

INTERNATIONAL FINANCE CORPORATION. Disponível em <http://www.ifc.org/wps/wcm/connect/Multilingual_Ext_Content/IFC_External_C orporate_Site/Home_PT>. Acessado em 22 jan. 2014.

O ESTADO DE SÃO PAULO. Disponível em: http://www.estadao.com.br/. Acessado em: diversas datas entre ago. 2012 e fev. 2014.

SUZANO PAPEL E CELULOSE. Disponível em: <http://www.suzano.com.br〉. Acessado em: diversas datas entre ago. 2011 e fev. 2014.

RELAÇÕES COM INVESTIDORES. Disponível em: http://ri.suzano.com.br. Acessado em: várias datas entre ago. 2012 e fev. 2014. VALOR ECONÔMICO. Disponível em: http://www.valor.com.br/. Acessado em: diversas datas entre ago. 2012 e fev. 2014. 